\title{
Biomarkers of Traumatic Brain Injury: Temporal Changes in Body Fluids
}

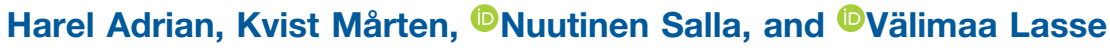

DOI:http://dx.doi.org/10.1523/ENEURO.0294-16.2016

Medicortex Finland Oy, Itäinen Pitkäkatu 4 B, 20520 Turku, Finland

\begin{abstract}
Traumatic brain injuries (TBIs) are caused by a hit to the head or a sudden acceleration/deceleration movement of the head. Mild TBIs (mTBls) and concussions are difficult to diagnose. Imaging techniques often fail to find alterations in the brain, and computed tomography exposes the patient to radiation. Brain-specific biomolecules that are released upon cellular damage serve as another means of diagnosing TBI and assessing the severity of injury. These biomarkers can be detected from samples of body fluids using laboratory tests. Dozens of TBI biomarkers have been studied, and research related to them is increasing. We reviewed the recent literature and selected 12 biomarkers relevant to rapid and accurate diagnostics of TBI for further evaluation. The objective was especially to get a view of the temporal profiles of the biomarkers' rise and decline after a TBI event. Most biomarkers are rapidly elevated after injury, and they serve as diagnostics tools for some days. Some biomarkers are elevated for months after injury, although the literature on long-term biomarkers is scarce. Clinical utilization of TBI biomarkers is still at a very early phase despite years of active research.
\end{abstract}

Key words: biomarker; diagnostics; TBI; traumatic brain injury

\section{Significance Statement}

Traumatic brain injury (TBI) is a common problem, called a "silent epidemic" because of a general unawareness of the condition. TBI is difficult to diagnose with imaging techniques, and there is no definite laboratory test to support the diagnosis. An undiagnosed case of TBI can result in premature "return to play" with severe consequences or in a chronic neurodegenerative condition later in life. An ideal laboratory test, detecting a brain injury-specific biomarker in one of the body fluids, would confirm or rule out the TBI, predict the outcome, and indicate when recovery is complete. This article reviews recent research on brain injury biomarkers that could be used for rapid and accurate diagnostics of TBI in easily accessible fluid samples.

\section{Introduction}

Traumatic brain injury (TBI) is caused by a blow to the head, penetration of foreign objects through the skull, or

\footnotetext{
Received September 30, 2016; accepted November 28, 2016; First published December 08, 2016.

Authors report no conflict of interest.

Author Contributions: All authors contributed equally to the search of references and writing of the paper.

Manuscript has been written at company's own cost.

Correspondence should be addressed to Dr. Harel Adrian, CEO, Medicortex Finland Oy, Itäinen Pitkäkatu 4 B, 20520 Turku, Finland. E-mail: adrian.harel@medicortex.fi.

DOI:http://dx.doi.org/10.1523/ENEURO.0294-16.2016

Copyright (C) 2016 Harel et al.
}

sudden motions of the head. A recent systematic review reports that the overall incidence rate of TBI is 262 in 100,000 , the mortality rate is 10.5 in 100,000 in Europe, and falls and road traffic accidents are the most common causes of TBI (Peeters et al., 2015). The statistics of the Centers for Disease Control and Prevention show that the overall incidence rate of TBI in the United States is 577 in 100,000 (total 1.7 million cases per year), and the mortality rate is 17.6 in $100,000(>51,000$ deaths per year; Faul

This is an open-access article distributed under the terms of the Creative Commons Attribution 4.0 International, which permits unrestricted use, distribution and reproduction in any medium provided that the original work is properly attributed. 


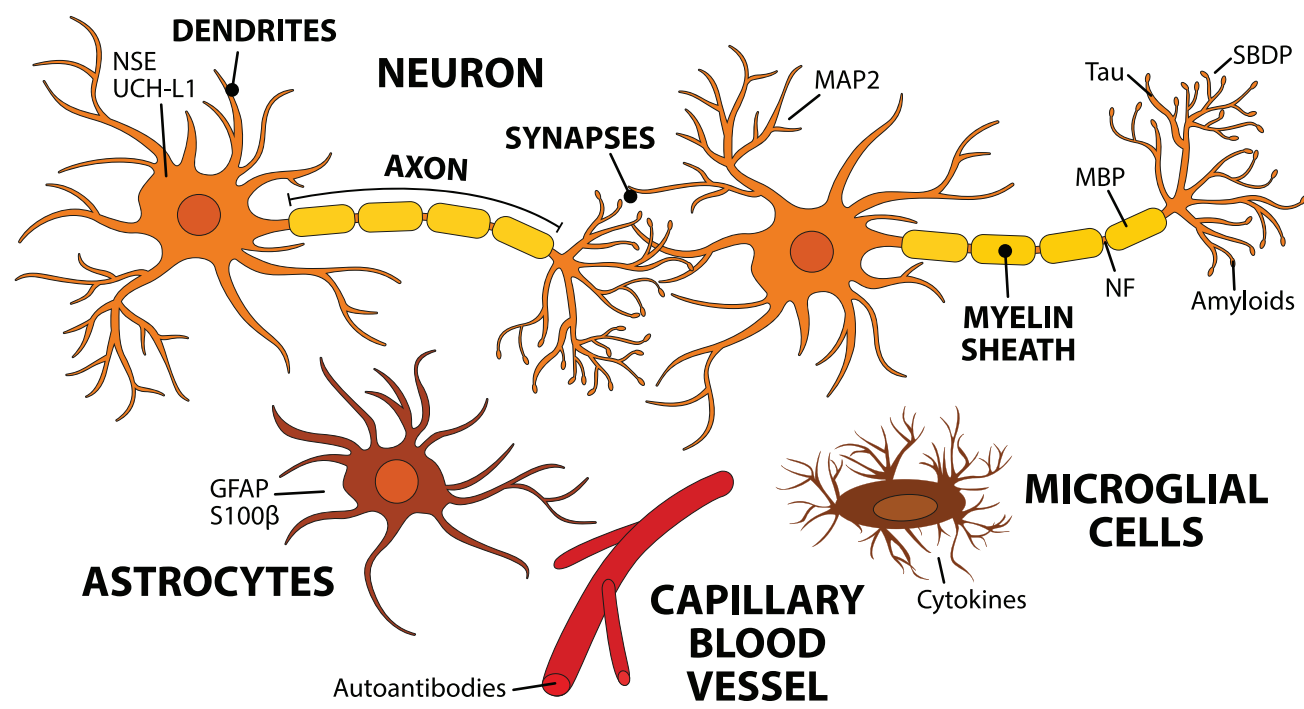

Figure 1. Biomarkers detected after TBI. This schematic figure demonstrates the possible cellular origin of the biomarkers that are associated with TBI pathology. TBI causes cellular injury to neuronal and nonneuronal cells. The trauma manifests in damaged BBB, ionic imbalances, energy depletion, and cell death. The cascade of events starts by an increase in extracellular glutamate and intra-axonal calcium levels. Increased calcium activates calpains, caspases, and phosphatases that trigger the cleavage of NFs and $\alpha$-spectrin, which leads to the disruption of the cytoskeleton and cell death. Calcium also activates transcription factors that upregulate inflammatory mediators, such as TNF- $\alpha$ and IL-1 $\beta$. In addition, mechanical injury causes synaptic dysfunction and accumulation and release of intracellular products, which impairs neurotransmission.

et al., 2010). It is estimated, however, that the presented numbers probably underestimate the incidence of mild $\mathrm{TBI}(\mathrm{mTBI})$, and the data are confounded by the great variation in the definitions of TBI.

The pathophysiology of TBI varies considerably depending on the location of the injury, the type of injury, and its severity. A mild injury may just cause a feeling of discomfort, headache, dizziness, or transient unconsciousness, whereas moderate or severe injuries may lead to diffuse axonal injury, epidural or subdural hematomas, intracerebral bleedings, large destruction of the brain tissue, and even death (Pearn et al., 2016).

Currently the diagnosis of TBI is made mainly based on a neurological examination of the patient and additionally using imaging radiology techniques such as computed tomography (CT) or magnetic resonance imaging (MRI). The Glasgow Coma Scale (GCS) assesses the severity of $\mathrm{TBI}$ on the basis of cognitive behavior (Teasdale and Jennet, 1974; Teasdale et al., 2014). A total score of 13-15 refers to mTBI, 9-12 to moderate TBI, and 3-8 to severe TBI (Faul and Coronado, 2015). Imaging techniques do not provide definitive means for the diagnostics of TBI, since they fail to find alterations in a large proportion of patients that have a mild to moderate injury (Hofman et al., 2001; Borg et al., 2004; Hughes et al., 2004; Belanger et al., 2007). One of the more advanced modes of MRI currently is diffusion tensor imaging (DT-MRI). It traces the direction of water molecules' diffusion and uses computed parameters of diffusivity as measures of axonal integrity (Delouche et al., 2016). The technique allows for accurate 3D modeling of neural tracts (tractography) by means of computerized image analysis. DT-MRI is considered a promising tool for TBI diagnostics because of the ability to focus on axonal structures, but the literature regarding the detection of acute $\mathrm{mTBI}$ is somewhat inconsistent. For example, Arfanakis et al. (2002) and Inglese et al. (2005) reported significant alterations in diffusivity after mTBI in particular brain areas, implying diffuse axonal injury (DAl), whereas Ilvesmäki et al. (2014) concluded that acute mTBI is not associated with white matter change on DT-MRI. Another special modality of $M R I$ is functional MRI (fMRI), which indicates the activation of various brain regions upon different stimuli or tasks. The imaging detects changes in cerebral blood flow and oxygen consumption based on different magnetic properties between oxyhemoglobin and deoxyhemoglobin. In the diagnostics of $\mathrm{mTBI}, \mathrm{fMRI}$ may be a promising technology. It has shown functional alterations in the brain of concussed athletes who were asymptomatic in clinical assessment and neuropsychological testing (Slobounov et al., 2011), and subtle changes have been detected even 1 year after an injury (McAllister et al., 2006). However, the literature regarding the diagnostics of acute $\mathrm{mTBI}$ using $\mathrm{fMRl}$ is scarce (McDonald et al., 2012).

Biomarkers of a brain injury (Fig. 1) can be detected in the cerebrospinal fluid (CSF) and in the blood directly after TBI (Zetterberg and Blennow, 2015). The blood-brain barrier (BBB), which normally is almost impermeable, can lose its integrity upon brain injury and allow the permeation of molecules into the blood (Başkaya et al., 1997). Alternatively, they may be transported to the blood via the glymphatic system (Plog et al., 2015). Urine is sampled noninvasively and can be an appropriate sample source in decentralized field assay conditions. The route of biomarkers from the brain to urine is indirect and contains potential barriers and dilutive interfaces, yet markers of brain injury have been found in urine (Rodríguez- 
Rodríguez et al., 2012; Ottens et al., 2014; Oliver et al., 2015).

Recent review articles discuss the biomarkers of TBI from various viewpoints, for example, comparison of body fluids as a source of biomarkers, their diagnostic and prognostic value, and the use of biomarkers in special situations such as sports and military accidents (Jeter et al., 2013; Yokobori et al., 2013; Zetterberg et al., 2013; Strathmann et al., 2014; Kulbe and Geddes, 2016). The timeline, or kinetics, of the emergence, persistence, and decline of the biomarkers is a rising area of active research. Acute biomarkers are valuable for the confirming or ruling out a brain injury shortly after a head injury. On the other hand, persistent biomarker levels can reveal a past TBI event. This information can help a person to avoid risky behavior that may result in a new head injury. It can also provide evidence for juridical processes and insurance claims related to an accident in which a head injury has occurred. In this review, we briefly introduce and discuss recent research and temporal courses studied on TBI biomarkers, focusing on body fluid samples that are easily accessible for rapid and specific diagnostics.

\section{Biomarkers}

\section{Biomarkers of TBI in body fluids $S 100 \beta$}

$\mathrm{S} 100 \beta$ is one member of the calcium binding protein family $\mathrm{S} 100$, which was first isolated from the bovine brain in 1965 (Moore, 1965). A relationship between neurological injury and $\mathrm{S} 100 \beta$ was discovered by Michetti et al. (1980). $S 100 \beta$ is expressed in astrocytes and other neural cells, but also in some cells of nonneural origin (summarized by Donato et al. 2009). High $S 100 \beta$ levels correlate with mortality and unfavorable prognosis (Mercier et al., 2013). However, $S 100 \beta$ is not brain injury specific: its concentration increases in some other diseases and traumas (Anderson et al., 2001; Undén et al., 2005; Studer et al., 2015), as well as during intensive physical exercise (Stocchero et al., 2014). A later sampling (12-36 h after trauma) of $S 100 \beta$ has shown enhanced prognostic value over early sampling (Thelin et al., 2013). Despite compromises in brain specificity, $\mathrm{S} 100 \beta$ has a good negative predictive value, and it is getting attention as a clinical marker to rule out a brain injury (Undén et al., 2013).

\section{S100 $\beta$ kinetics}

A study by Rodríguez-Rodríguez et al. (2012) showed a peak in serum $<6 \mathrm{~h}$ after injury and thereafter a gradual decrease until the end of the follow-up period (96 h). Thelin et al. (2014) reported that a secondary peak (a new rise even as low as $0.05 \mu \mathrm{g} / \mathrm{l}$ ) detected in serum $\geq 48 \mathrm{~h}$ after trauma strongly correlated with later pathological findings in CT and MRI. A comprehensive kinetic modeling by Ercole et al. (2016) confirms that a relatively sharp peak of $S 100 \beta$ occurs in serum just 1 day after trauma (mean time to peak, $27.2 \mathrm{~h}$ ). $\mathrm{S} 100 \beta$ has also been studied in urine. A study showed a peak at admission $(\leq 6 \mathrm{~h}$ postinjury) and a subsequent decrease until $48 \mathrm{~h}$, after which the concentration slightly increased until $96 \mathrm{~h}$
(Rodríguez-Rodríguez et al., 2012). Another study in urine (pediatric patients) showed that $\mathrm{S} 100 \beta$ peaked at a mean of $55.3 \mathrm{~h}$ after injury (Berger and Kochanek, 2006). The peak in serum appeared significantly earlier, at a mean of $14.6 \mathrm{~h}$ after injury. Overall, the concentration of $\mathrm{S} 100 \beta$ in the blood rises and peaks in some hours, but then it decreases quite rapidly, since the half-life of $S 100 \beta$ in serum is only on the order of $1.5 \mathrm{~h}$ (Townend et al., 2006).

\section{Glial fibrillary acidic protein}

Glial fibrillary acidic protein (GFAP) is an intermediate filament protein that was reported for the first time in 1971 (Eng et al., 1971), and its relation to brain injuries was elucidated later in animal studies (Latov et al., 1979; Moore et al., 1987). GFAP is abundantly expressed in the cytoskeleton of astrocytes, although some expression in other types of cells has been discovered (Kasantikul and Shuangshoti, 1989). However, several studies confirm the high specificity of GFAP to brain injuries in comparison to other biomarkers such as $\mathrm{S} 100 \beta$ and neuron-specific enolase (Honda et al., 2010; Papa et al., 2014, 2016b). The concentration of GFAP in serum differs between patients that have a GCS value of 3-5 and 13-15, and thus, GFAP has diagnostic potential to discriminate between severe and mild cases of TBI (Lee et al., 2015). Acute GFAP levels correlate with the recovery and outcome of the patient (Mannix et al., 2014; Takala et al., 2016), although in mTBI cases, the predictive value was found to be weaker (Metting et al., 2012).

\section{GFAP kinetics}

One of the earliest studies (Missler et al., 1999) measuring GFAP in human blood reported that admission samples (3-16 h postinjury) showed increased levels of blood GFAP in 12 of 25 patients, with a mean concentration of $0.10 \mu \mathrm{g} / \mathrm{l}$. Approximately $85 \%$ of the healthy controls were below the detection limit of $0.010 \mu \mathrm{g} / \mathrm{l}$. In 24and 48-h samples, GFAP was detectable in a smaller number of patients, and the levels were only slightly elevated. A more recent study (Lei et al., 2015), which followed the levels of GFAP for $0-5$ days after the injury, reported that the peak was detected at admission (0.5-4 h). Žurek and Fedora (2012) monitored children that had $\mathrm{TBI}$, and they also found the highest levels of GFAP in the admission samples drawn $<12 \mathrm{~h}$ after injury. The GFAP levels were much higher in nonsurvivors compared with survivors; however, the temporal profiles were similar in both groups during the 6-day follow-up period. Papa et al. (2016a) monitored GFAP levels at short intervals in patients enrolled no more than $4 \mathrm{~h}$ after injury. They found that GFAP was detectable in serum within $1 \mathrm{~h}$, and the peak appeared at $20 \mathrm{~h}$ in patients who had a mild or moderate TBI. Other studies have also confirmed that GFAP is detectable in serum as early as $1 \mathrm{~h}$ after the injury (Papa et al., 2014, 2015b).

\section{Neuron-specific enolase}

Enolases are enzymes that catalyze the conversion of 2-phosphoglycerate into phosphoenolpyruvate in the glycolysis pathway. Evidence on the existence of a brainspecific enolase came forth in the 1970s (Bock and 
Dissing, 1975; Rider and Taylor, 1975). Known as neuronspecific enolase (NSE), $\gamma$-enolase, or enolase 2, the neuron-specific isoenzyme consists of two $\gamma$-subunits $(\gamma \gamma)$ with a total molecular weight of $78 \mathrm{kDa}$. Increased levels of NSE in the serum of TBI patients were first observed in the early 1990s (Skogseid et al., 1992). A recent meta-analysis reports that high concentrations of NSE in serum is significantly associated with mortality and unfavorable outcome (Cheng et al., 2014). A risk related to the use of NSE is that the samples may be contaminated by enolases from hemolyzed red blood cells (Ramont et al., 2005), although improved accuracy can be obtained with a correction factor (Tolan et al., 2013). The presence and diagnostic value of NSE is not clear in MTBI and concussion, however, as a significant elevation of NSE in the serum was detected after kicks to the head in karate (Graham et al., 2015) but not in concussed ice hockey players (Shahim et al., 2014).

\section{NSE kinetics}

Herrmann et al. (2000) reported that the temporal profiles of NSE in serum differed significantly between groups with $\mathrm{mTBI}$ and moderate to severe TBI, but the concentration came down to the normal level in 25-48 h even in the severe TBI group. Further, in cases of DAI and intracranial pressure, the peak of NSE appeared on the third day. Žurek and Fedora (2012) also found different severity-dependent profiles in children; whereas the concentration of NSE gradually decreased after injury in survivors, nonsurvivors had increasing NSE concentrations during days 1 and 2 . A recent study analyzed serum NSE levels for $5 d$ after severe TBI (Olivecrona et al., 2015). The initial NSE level (sampled on average $15 \mathrm{~h}$ postinjury) reached $\sim 19 \mu \mathrm{g} / \mathrm{l}$ and gradually decreased to $\sim 8 \mu \mathrm{g} / \mathrm{l}$ until day 5 . The study also showed an association of NSE levels with intracranial pressure, cerebral perfusion pressure, and CT findings.

\section{Ubiquitin C-terminal hydrolase- L1}

Ubiquitin carboxy-terminal hydrolase L1 (UCH-L1), also known as protein gene product 9.5 (PGP 9.5), is a $27-k D a$ enzyme abundant in the soma of neurons. $\mathrm{UCH}-\mathrm{L} 1$ cleaves ubiquitin, a small regulatory protein involved in labeling proteins for metabolism, from the $\mathrm{C}$ terminus of its target proteins. $\mathrm{UCH}-\mathrm{L} 1$ was discovered in the 1980s and constitutes some $1-5 \%$ of the brain's total protein content (Doran et al., 1983; Wilkinson et al., 1989).

Active research on $\mathrm{UCH}-\mathrm{L} 1$ in the context of TBI has emerged since the first decade of the 2000s (Siman et al., 2009; Papa et al., 2010). UCH-L1 has been shown to be a brain-specific biomarker, and its levels correlate with the severity of TBI and outcome (Mondello et al., 2012b; Takala et al., 2016). In mTBIs, the results are inconsistent; Papa et al. (2012) reported that serum UCH-L1 levels discriminate mTBls from controls, whereas some studies were unable to show a sufficient discriminating power between patients with $\mathrm{mTBI}$ and noninjured controls (Berger et al., 2012; Puvenna et al., 2014). However, UCH-L1 was shown to outperform GFAP and $S 100 \beta$ when the goal was to reduce CT scans in patients with mild to moderate TBI (Welch et al., 2016).

\section{UCH-L1 kinetics}

The concentration of $\mathrm{UCH}-\mathrm{L} 1$ in serum rises within a few hours after injury, but the level also declines quite fast (Brophy et al., 2011; Mondello et al., 2012b). In cases of mild to moderate TBI, the concentration of $\mathrm{UCH}-\mathrm{L} 1$ was shown to peak in $8 \mathrm{~h}$ after injury, which was earlier than the peak of GFAP (Papa et al., 2016a). The time window for the detection of UCH-L1 was short, but the authors discussed that the rapid rise of $\mathrm{UCH}-\mathrm{L} 1$ enables the assaying of $\mathrm{TBI}$ in point-of-care settings at the accident site or in ambulances.

\section{Neurofilaments}

The neuronal cytoskeleton is mainly composed of neurofilaments (NFs), which is one subcategory (Type IV) of intermediate filaments. The three main proteins (NF subunits) that compose neurofilaments are named according to their sizes: light (NF-L, 68-70 kDa), medium (NF-M, $145-160 \mathrm{kDa}$ ), and heavy (NF-H, 200-220 kDa). Neurofilaments are localized in the axon, and they regulate the structure and diameter of a neuron (Trojanowski et al., 1986). The phosphorylated form of the heavy subunit (p-NF-H) is specific to axons and can be detected in the blood with an immunoassay, thus being a potential biomarker of DAl (Shaw et al., 2005; Anderson et al., 2008). Gatson et al. (2014) reported that the level of p-NF-H was significantly increased in the serum of $\mathrm{mTBI}$ patients and clearly distinguished patients from noninjured controls. It was also shown that p-NF-H is a decent predictive marker of outcome in adult TBI patients (Shibahashi et al., 2016).

\section{NF kinetics}

The kinetic profile of $\mathrm{p}-\mathrm{NF}-\mathrm{H}$ in serum differs somewhat from that of many other biomarkers. Although several biomarkers peak and then decline within a couple of days after injury, the concentration of p-NF-H still increases. The continuous increase was shown with a pediatric population during 6 consecutive days (Žurek and Fedora, 2012), and in another study within 4 up to 10 days after injury (Vajtr et al., 2012).

\section{Myelin basic protein}

Oligodendrocytes and Schwann cells produce the myelin sheath of the axons. The myelin sheath contains lipids and proteins, and the main protein component of the myelin sheath is myelin basic protein (MBP), which comprises $\sim 30 \%$ of myelin's protein content. Myelination is an age-dependent process, and thus the amount of myelin in the CNS varies between children and adults (Steinman, 1996; Paus et al., 2001). The relation of MBP to TBI was discovered in the late 1970s (Thomas et al., 1978). MBP has been found to correlate specifically with clinical outcome (Yamazaki et al., 1995; Berger et al., 2005).

\section{MBP kinetics}

MBP can be detected already $1.5-8.0 \mathrm{~h}$ after injury (Yamazaki et al., 1995), but MBP peaks somewhat slower than S100 $\beta$ and NSE (Berger et al., 2005, 2006). Serum MBP remains elevated for even up to 2 weeks (Thomas et al., 1978). The time course of MBP was 
shown to be different in various types of TBI; in pediatric patients, serum MBP peaks later in inflicted TBI compared with noninflicted TBI (Berger et al., 2005, 2006). Specific temporal patterns thus may help in distinguishing brain injury induced by child abuse from accident-based brain injuries.

\section{Spectrin breakdown products}

Spectrin is a cytoskeletal protein that maintains cell membrane integrity and cytoskeleton structure (De Matteis and Morrow, 2000). Upon cellular injury, calpains and caspases cleave spectrin to spectrin breakdown products (SBDPs). Different SBDPs are present depending on the type of cell death and the enzymes involved in the process (Wang et al., 1998; Büki et al., 2000). A relevant SBDP for brain injuries is calpain-derived $\mathrm{N}$-terminal $\alpha$ llspectrin fragment (SNTF), which can be readily detected in concussions, but also in a subset of orthopedic injuries (Siman et al., 2013, 2015).

\section{SBDP kinetics}

In concussed ice hockey players, the concentration of serum SNTF increased above the prior measured preseason level $1 \mathrm{~h}$ after head injury. In persistent concussion ( $\geq 6$ days), serum SNTF was increased as much as 2.5fold above the baseline and stayed elevated from $1 \mathrm{~h}$ to 6 days. The average of the 12- to 36-h postinjury serum level showed the greatest accuracy in discriminating persistent concussions from milder concussions whose symptoms were alleviated within a few days (Siman et al., 2015).

Tau

Tau is one of the microtubule-associated proteins (MAPs) that were discovered in the 1970s (Weingarten et al., 1975; Witman et al., 1976). Tau is a 48- to $68-\mathrm{kDa}$ protein that stabilizes microtubular assembly and is enriched in the axons of neurons, although it is not completely specific for the CNS (Goedert et al., 1989; Morris et al., 2011). Upon cellular injury and activation of proteases, tau is cleaved into fragments of $10-18 \mathrm{kDa}$ and 30-50 kDa (cleaved tau or c-tau; Zemlan et al., 1999; Gabbita et al., 2005). In addition, injuries lead to the phosphorylation of tau, which in extreme cases results in the aggregation of hyperphosphorylated fragments (tau tangles) that are characteristic for neurodegenerative diseases such as Alzheimer's disease and chronic traumatic encephalopathy (Šimić et al., 2016).

Clearly elevated levels of serum tau with reliable prognostic value have been reported after severe TBI (Liliang et al., 2010). In mTBI, serum tau levels were also increased, but the difference from the noninjured controls was not statistically significant (Bulut et al., 2006), and weaker prognostic values have been reported (Bazarian et al., 2006; Ma et al., 2008). However, new sensitive assay techniques have shown enhanced diagnostic performance for tau between injured and noninjured samples and an advantage for the use of tau in cases where many other biomarkers have failed to detect brain injury (Neselius et al., 2013; Shahim et al., 2014; Olivera et al., 2015; Rubenstein et al., 2015).

\section{Tau kinetics}

Ultrasensitive immunoassays have revealed temporal profiles of tau in blood. Among concussed ice hockey players, the highest total tau levels in plasma were measured during the first hour after a concussion, and the level declined already during the first $12 \mathrm{~h}$. In addition, a trend to a second peak at $36 \mathrm{~h}$ after concussion was observed (Shahim et al., 2014). Phosphorylated tau remains elevated in serum longer than total tau (Rubenstein et al., 2015). Elevated levels of total tau in plasma were measured among soldiers who had suffered TBI during their deployment within the past 18 months, thus indicating that tau may serve as a long-term biomarker of an earlier TBI event (Olivera et al., 2015).

\section{Microtubule-associated protein 2}

Microtubule-associated protein 2 (MAP2), like tau, belongs to the family of microtubule stabilizing proteins. MAP2 is abundant in nerve cells and is believed to be specific for neurons' dendritic injuries (Garner et al., 1988). Elevated levels of MAP2 were detected in the serum of severe TBI patients at 6 months after injury (Mondello et al., 2012a). Survivors of TBI had higher levels of MAP2 than patients that had gone into a vegetative state. The authors concluded that a severe TBI results in a chronic release of MAP2, but it is also a marker of remodeling and indicates emergence into the higher level of consciousness for TBI patients.

\section{MAP2 kinetics}

MAP2 is a novel biomarker of TBI, and the above 6 -month time point is the only temporal data on the presence of MAP2 in human blood; it suggests that MAP2 can indicate a past TBI event. In human CSF, MAP2 was found to be elevated within $6 \mathrm{~h}$ after injury, and the concentration remained quite stable for at least $24 \mathrm{~h}$ (Papa et al., 2015a).

\section{Amyloid $\beta$}

Amyloid precursor protein is a cell surface receptor and a transmembrane precursor protein that is cleaved to various peptides, including amyloid $\beta(A \beta)$, which is a 36to 43-aa-long peptide abundant in amyloid plaques, characteristic of Alzheimer's disease (Vivekanandan et al., 2011; Tharp and Sarkar, 2013). Abnormal concentrations or altered structure of $A \beta$ is neurotoxic. $A \beta$ plaques have been found in $\sim 30 \%$ of TBI patients, and TBI is considered an independent risk factor for Alzheimer's disease (Roberts et al., 1994; Tsitsopoulos and Marklund, 2013). Immunohistochemical staining has shown that the accumulation of amyloid precursor protein in injured axons and thus $A \beta$ could be a biomarker of diffuse axonal injury (Johnson et al., 2016).

\section{Amyloid $\beta$ kinetics}

Using an ultrasensitive digital ELISA, Mondello et al. (2014) found that $A \beta_{42}$ rises in the plasma within the first day after injury, and the level remains quite steady for at least $6 \mathrm{~d}$ after injury. In contrast, one study reported no change in the plasma $A \beta_{42}$ level during a follow-up of up to 11 days after severe TBI (Olsson et al., 2004). 
Table 1. Laboratory tests for the biomarkers reviewed in this article that are available in hospital laboratories.

\begin{tabular}{|c|c|c|c|c|}
\hline Biomarker & Sample & Method & Normal range & Range in TBI \\
\hline $\mathrm{S} 100 \beta$ & Serum & IC & $<0.11 \mu \mathrm{g} / \mathrm{l}$ & $>0.11 \mu \mathrm{g} / \mathrm{l}^{\mathrm{a}}$ \\
\hline \multirow[t]{2}{*}{ NSE } & Serum & $\begin{array}{l}\text { Immunodetection } \\
\text { based on ECL }\end{array}$ & From $<17$ to $<25 \mu \mathrm{g} / \mathrm{l}$, depending on age & $>20 \mu \mathrm{g} / \mathrm{I}^{\mathrm{a}}$ \\
\hline & CSF & $\begin{array}{l}\text { Immunodetection } \\
\text { based on ECL }\end{array}$ & $<15 \mu \mathrm{g} / \mathrm{l}$ & $54.80 \pm 43.34 \mu \mathrm{g} / \mathrm{l}^{\mathrm{b}}$ \\
\hline P-tau & CSF & ELISA & $<70 \mathrm{pg} / \mathrm{ml}$ & N/A \\
\hline Tau & CSF & ELISA & $<400 \mathrm{pg} / \mathrm{ml}$ & $1684-8691 \mathrm{pg} / \mathrm{ml}^{\mathrm{C}}$ \\
\hline$A \beta-42$ & CSF & ELISA & $>500 \mathrm{pg} / \mathrm{ml}$ & $\begin{array}{l}<230 \mathrm{pg} / \mathrm{ml}^{\mathrm{d}} \\
<350 \mathrm{pg} / \mathrm{ml}^{\mathrm{e}}\end{array}$ \\
\hline IL-6 & Plasma & IC & $<5.9 \mathrm{ng} / \mathrm{l}$ & N/A \\
\hline IL-8 & Plasma & IC & $<62$ ng/l & $\mathrm{N} / \mathrm{A}$ \\
\hline TNF- $\alpha$ & Serum & IC & $<8.1 \mathrm{ng} / \mathrm{l}$ & $\mathrm{N} / \mathrm{A}$ \\
\hline
\end{tabular}

The assays shown in the table respond to the head injuries and to the conditions of the central nervous system, but only $\mathrm{S} 100 \beta$ has TBI as the main indication. The data were collected from the laboratory manuals of large hospitals in September 2016. IC, immunochemiluminescence; ECL, electrochemiluminescence; A $\beta-42$, amyloid-beta-42 protein. ${ }^{a}$ Reference values defined in clinical laboratories. ${ }^{b}$ Brandner et al. (2013). ${ }^{\mathrm{c} M a g n o n i}$ et al.(2012). ${ }^{\mathrm{d}}$ Franz et al. (2003). "Mondello et al.(2014).

\section{Cytokines}

Neuroinflammation is an essential part of the secondary injury cascade after TBI. Several proinflammatory cytokines and chemokines are upregulated, and they recruit immune cells into the CNS and promote astrogliosis (Hellewell et al., 2016). The CNS inflammatory response initiates already a few minutes after injury, and proinflammatory mediators are highly elevated in situ, whereas anti-inflammatory cytokines remain unchanged (Frugier et al., 2010). Tuttolomondo et al. (2014) reported that tumor necrosis factor (TNF)- $\alpha$, especially, plays an essential role in mediating an immune response in TBI and ischemic stroke. Interleukin (IL)-6 is considered another central mediator in neuroinflammation; increased levels of IL-6 in serum have been found after acute cerebral ischemia and correlated with poor functional and neurological outcome (Fassbender et al., 1994). Also, elevated levels of a small chemokine in plasma, chemokine CC ligand-2 (formerly monocyte chemoattractant protein 1) correlated with the severity of TBI (Ho et al., 2012).

\section{Cytokine kinetics}

High levels of cytokines have been measured predominantly in the CSF, where they peak within the first days after injury and where the concentrations of several cytokines are typically higher than in the blood (Kossmann et al., 1997; Csuka et al., 1999; Maier et al., 2001). However, Santarsieri et al. (2015) found several inflammation markers in significantly higher concentrations in the serum than in the CSF. Similar kinetic trends as in the CSF have been detected in the serum, i.e., peaking within the first days, and also a mild secondary rise of $\mathrm{IL}-10$ in the second week (Csuka et al., 1999; Hayakata et al., 2004). Elevated levels of several cytokines in serum were measured for $>3$ months after a TBI, which indicate the presence of chronic post-TBI inflammation (Kumar et al., 2015).

\section{Autoantibodies}

Autoantibodies against brain proteins have been known for some time; recently, they have gained interest in serving as diagnostic tools for CNS injury (Kobeissy and Moshourab, 2015). Disrupted BBB due to TBI permits the leakage of brain proteins and their breakdown products into the circulation, and in some cases, antibodies against these released self-antigens are generated (Raad et al., 2014). Autoantibodies remain in the blood quite a long time, and therefore they present a new class of biomarkers for a past TBI event and chronic sequelae.

Autoantibodies against GFAP and its breakdown products have been recently reported in the context of TBI. When the sera of severe TBI patients were screened using brain immunoblots, a significant increase in the amount of GFAP-specific antibodies was detected beginning at day 5 after TBI (Zhang et al., 2014). The concentrations of GFAP-specific autoantibodies were found to be significantly higher in TBI patients compared with healthy controls at 6 months after injury (Wang et al., 2016). In addition, autoantibodies against $\mathrm{S} 100 \beta$ were detected in the serum of football players during season (Marchi et al., 2013). The autoantibody levels correlated with the $S 100 \beta$ levels measured shortly after each game. The players that were enrolled in the study had suffered regular repeated hits to the head but no concussion or TBI during the game. The authors concluded that even subconcussive hits disrupted the BBB and permitted the leakage of $\mathrm{S} 100 \beta$ into the blood and subsequent generation of autoantibodies.

\section{Biomarkers of TBI in clinical laboratories}

Of the biomarkers presented in this review, some are available (Table 1) in hospital laboratories, according to the laboratory manuals of large hospitals (Fimlab Laboratories Oy; Hospital District of Helsinki and Uusimaa; Hospital District of Southwest Finland; University of Eastern Finland, Brain Research Unit). Several laboratory assays respond to TBI and other abnormal conditions of CNS. However, $\mathrm{S} 100 \beta$ is the only one that has TBI as the main indication. The main indications of NSE are neuroblastoma and small cell lung cancer. Tau and $A \beta$ are a biomarkers of Alzheimer's disease, and cytokines are general biomarkers of inflammation and sepsis. The Scandinavian Neurotrauma Committee has recommended the analysis of serum $S 100 \beta$ of head trauma patients who have a mild injury (GCS 14-15) and can be sampled within $6 \mathrm{~h}$ after 


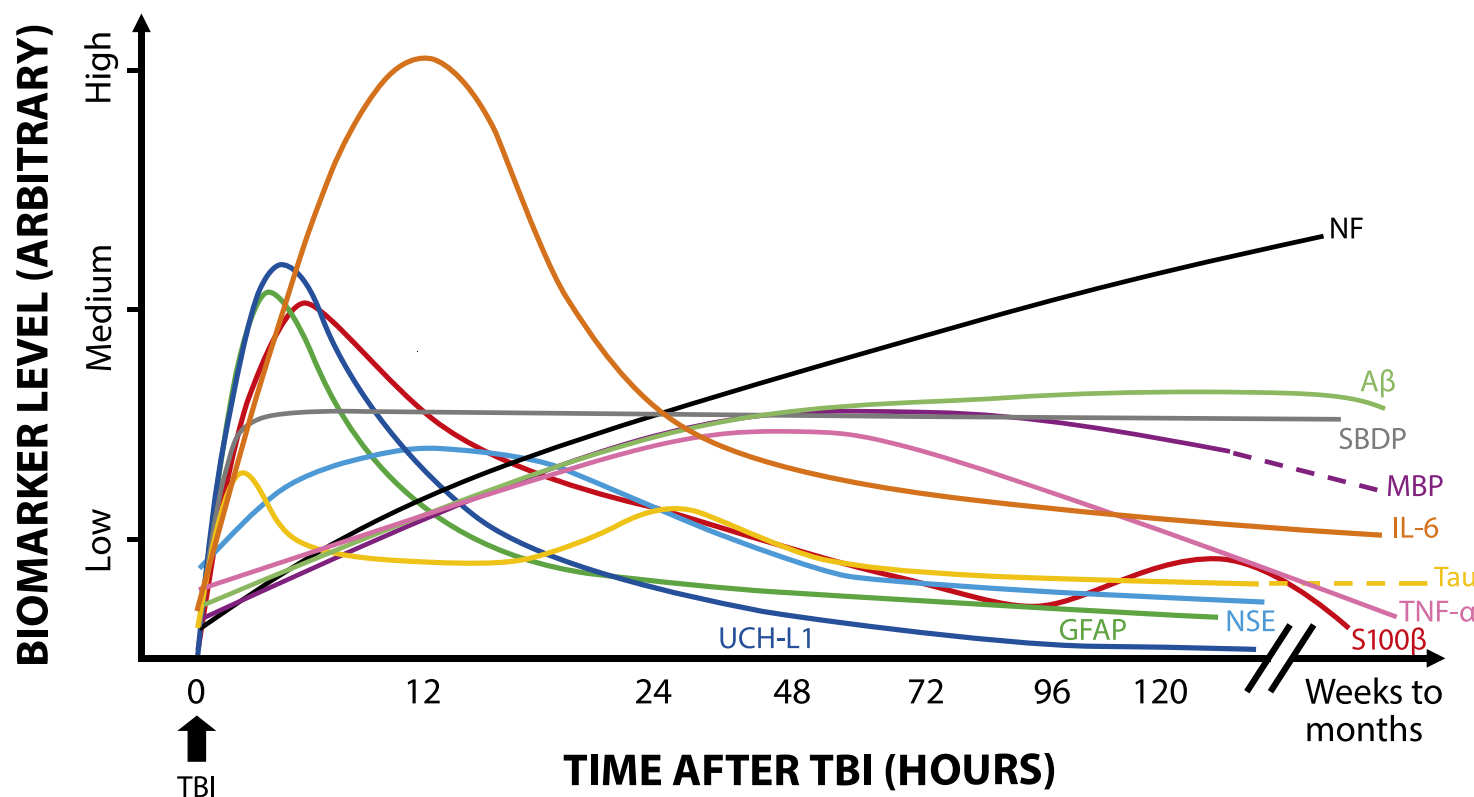

Figure 2. Kinetics of TBI biomarkers. Schematic representation shows the rise and decline of the TBI biomarkers for which representative kinetic data were available in serum or plasma. Separate long-term values (months to weeks) are included when possible.

injury (Undén et al., 2013). The concentration of $0.1 \mu \mathrm{g} / \mathrm{l}$ is considered the cutoff for a CT scan (see Discussion). The validation of these guidelines showed that approximately one third of CT scans for mild TBI cases can be avoided with little or no impact on patient outcome (Undén et al., 2015). Diagnostic kits for $S 100 \beta$ are available from several manufacturers; however, clinical comparison of kits' performance has shown that the results are not interchangeable between different suppliers' assays (Müller et al., 2006; Hallén et al., 2008; Erickson and Grenache, 2011).

\section{Nonclassic brain injury markers}

The glymphatic system has been suggested to serve as a clearance pathway of interstitial fluid and solutes from the brain parenchyma, and also as a potential route of brain injury biomarkers from the brain to the blood (lliff et al., 2012; Plog et al., 2015). Interestingly, the pathway itself is impaired after TBI as well. lliff et al. (2014) found progressive impairment of CSF-interstitial fluid exchange within the glymphatic pathway 1-28 days after TBI. The dysfunction of the glymphatic system results in the accumulation of tau and $A \beta$, thus promoting the development of neurofibrillary pathology and neurodegeneration. It may be possible to assay the integrity of the glymphatic pathway in vivo by using appropriate contrast agents, and this might in the future serve as a highly sensitive novel indicator of brain injury.

\section{Discussion}

We reviewed recent research on TBI biomarkers with special focus on the time course of the markers in easily accessible body fluids relevant for rapid diagnostics. The usual approach in several studies is that the follow-up of the biomarkers starts upon the admission of the patient to the hospital and continues at various intervals for different periods of time, typically a few days to $\sim 1$ week. The admission of the patient to the hospital and the time of the first sampling occurs some time after the accident; thus the first measures in the sequence represent a time point of a few hours after injury at the least. There are hardly any data on the very early kinetics of biomarkers in human subjects because of the lack of rapid tests useful for paramedics and ambulances. Several studies were made on patients who had sustained moderate to severe TBI. Concussions and mTBls bear less cellular injuries, and the overall release of intracellular molecules is lower, making their measurement more demanding, especially in the blood, because of barriers and dilution, which happens when a molecule traverses from brain to the blood.

The time profiles of the biomarkers evidently represent different molecular origins and release mechanisms. Many biomarkers are released during the first burst upon cellular injury and the concomitantly triggered degradation processes. Those markers peak early, within a few hours, and then decline after the molecule-specific halflife in the blood. Neuroinflammation and the emergence of cytokines are somewhat slower processes, and therefore cytokines peak in $<48 \mathrm{~h}$. Autoantibodies against brain proteins rise slowly but stay elevated for a fairly long time. The temporal profiles and the relative levels presented in Figure 2 are approximate and must be read with consideration in the absence of uniform data collection and research methods. For example, the severity of TBI affects the peak heights and durations.

Awareness of the temporal profiles of the biomarkers is essential when defining and setting the most appropriate diagnostic time window for sampling after injury. Furthermore, integrated area under the time-curve as a diagnostic determinant, instead of just a single time point measurement, can give advanced diagnostic performance, as shown by Brophy et al. (2011). In addition, the 
trend between successive measurements indicates the progression of the injury. For example, a TBI patient who was originally considered a mild case showed continuous increase of NSE and S100 $\beta$ until the patient died at $76 \mathrm{~h}$ after admission. The mean values of those biomarkers, as calculated from all patients of the group in the study, showed descending trends, however (Herrmann et al., 2000). This is something that frequently remains undisclosed in several study reports; temporal profiles are shown as mean values of the patient cohort or mean values of patient categories (e.g., mild and severe trauma), although follow-up of individual trends would reveal some essential information that is hidden within the mean values.

Recently published Scandinavian guidelines (Undén et al., 2013, 2015) recommend for the first time to measure the biomarker $S 100 \beta$ in the serum of patients who have sustained a mild head injury. The biomarker $S 100 \beta$ should be assayed in cases where the GCS is 14 and no other risks are present, and when the GCS is 15 and the patient has a history of loss of consciousness and repeated vomiting. The guidelines recommend that the patients mentioned above are admitted to CT imaging only when the concentration of $\mathrm{S} 100 \beta$ is $\geq 0.10 \mu \mathrm{g} / \mathrm{l}$. This approach reduces the number of CT scans by approximately one third and saves those patients from unnecessary exposure to radiation (Undén et al., 2015). The $S 100 \beta$ assay has a good negative predictive value (Undén and Romner, 2010; Asadollahi et al., 2015), meaning that a negative value of $S 100 \beta$ quite reliably rules out brain injury in any patient. Increased levels of $S 100 \beta$ may originate from a brain injury, but also from lesions in some other tissues. This means that a positive value of $S 100 \beta$ does not necessarily confirm the presence of a brain injury, especially in multitrauma patients (Sorci et al., 1999; Undén et al., 2013; Gebhardt et al., 2016; Wolf et al., 2016).

$\mathrm{TBI}$, its consequences, and other brain traumas are admittedly gaining increasing awareness in society. The detection of these conditions, as well as the overall assaying of brain status and recovery after injury, is not unambiguous, however. Biomarkers that can be measured from body fluids in regular laboratory practice, or even in decentralized conditions, can supplement diagnosis or perhaps serve as a new means of definitive diagnosis for mild injuries. But, consensus and coherence among TBI biomarkers is still missing, and $S 100 \beta$ is the only one that is gradually being implemented into clinical use. Some trends for the future can be seen, however, as diagnostic technologies develop and can detect smaller molecular quantities with higher resolving power. This can bring some current biomarkers into new light. Second, multiplexing - detection of several biomarkers in parallel in one assay - has been adapted in TBI biomarker study as well (Diaz-Arrastia et al., 2014; Di Battista et al., 2015). Furthermore, proteomic (and other "-omic") approaches can discover new brain injury-related biomolecules which can be harnessed and validated in time into new diagnostic TBI biomarkers.

\section{References}

Anderson KJ, Scheff SW, Miller KM, Roberts KN, Gilmer LK, Yang C, Shaw G (2008) The phosphorylated axonal form of the neurofilament subunit NF-H (pNF-H) as a blood biomarker of traumatic brain injury. J Neurotrauma 25:1079-1085. CrossRef Medline

Anderson RE, Hansson LO, Nilsson O, Dijlai-Merzoug R, Settergren G (2001) High serum S100B levels for trauma patients without head injuries. Neurosurgery 48:1255-1258. 1260. Medline

Arfanakis K, Haughton VM, Carew JD, Rogers BP, Dempsey RJ, Meyerand ME (2002) Diffusion tensor MR imaging in diffuse axonal injury. AJNR Am J Neuroradiol 23:794-802. Medline

Asadollahi S, Heidari K, Taghizadeh M, Seidabadi AM, Jamshidian M, Vafaee A, Manoochehri M, Shojaee AH, Hatamabadi HR (2015) Reducing head computed tomography after mild traumatic brain injury: screening value of clinical findings and S100B protein levels. Brain Inj 30:172-178. CrossRef Medline

Bașkaya MK, Rao AM, Doğan A, Donaldson D, Dempsey RJ (1997) The biphasic opening of the blood-brain barrier in the cortex and hippocampus after traumatic brain injury in rats. Neurosci Lett 226:33-36. Medline

Bazarian JJ, Zemlan FP, Mookerjee S, Stigbrand T (2006) Serum S-100B and cleaved-tau are poor predictors of long-term outcome after mild traumatic brain injury. Brain Inj 20:759-765. CrossRef Medline

Belanger HG, Vanderploeg RD, Curtiss G, Warden DL (2007) Recent neuroimaging techniques in mild traumatic brain injury. J Neuropsychiatr Clin Neurosci 19:5-20. CrossRef Medline

Berger RP, Adelson PD, Pierce MC, Dulani T, Cassidy LD, Kochanek PM (2005) Serum neuron-specific enolase, S100B, and myelin basic protein concentrations after inflicted and noninflicted traumatic brain injury in children. J Neurosurg 103:61-68. CrossRef

Berger RP, Adelson PD, Richichi R, Kochanek PM (2006) Serum biomarkers after traumatic and hypoxemic brain injuries: insight into the biochemical response of the pediatric brain to inflicted brain injury. Dev Neurosci 28:327-335. CrossRef Medline

Berger RP, Hayes RL, Richichi R, Beers SR, Wang KKW (2012) Serum concentrations of ubiquitin C-terminal hydrolase-L1 and $\alpha$ ll-spectrin breakdown product $145 \mathrm{kDa}$ correlate with outcome after pediatric TBI. J Neurotrauma 29:162-167. CrossRef

Berger RP, Kochanek PM (2006) Urinary S100B concentrations are increased after brain injury in children: a preliminary study. Pediatr Crit Care Med 7:557-561. CrossRef Medline

Bock E, Dissing J (1975) Demonstration of enolase activity connected to the brain-specific protein 14.3.2. Scand J Immunol 4:31-36. CrossRef

Borg J, Holm L, Cassidy JD, Peloso PM, Carroll LJ, von Holst H, Ericson K, Collaborating Centre Task Force on Mild Traumatic Brain Injury WHO (2004) Diagnostic procedures in mild traumatic brain injury: results of the WHO Collaborating Centre Task Force on Mild Traumatic Brain Injury. J Rehabil Med (43 Suppl):61-75. CrossRef

Brandner S, Thaler C, Buchfelder M, Kleindienst A (2013) Brainderived protein concentrations in the cerebrospinal fluid: contribution of trauma resulting from ventricular drain insertion. J Neurotrauma 30:1205-1210. CrossRef Medline

Brophy GM, Mondello S, Papa L, Robicsek SA, Gabrielli A, Tepas J, Buki A, Robertson C, Tortella FC, Hayes RL, Wang KKW (2011) Biokinetic analysis of ubiquitin C-terminal hydrolase-L1 (UCH-L1) in severe traumatic brain injury patient biofluids. J Neurotrauma 28:861-870. CrossRef

Büki A, Okonkwo DO, Wang KK, Povlishock JT (2000) Cytochrome c release and caspase activation in traumatic axonal injury. J Neurosci 20:2825-2834. Medline

Bulut M, Koksal O, Dogan S, Bolca N, Ozguc H, Korfali E, Ilcol YO, Parklak M (2006) Tau protein as a serum marker of brain damage in mild traumatic brain injury: preliminary results. Adv Ther 23:1222. Medline

Cheng F, Yuan Q, Yang J, Wang W, Liu H (2014) The prognostic value of serum neuron-specific enolase in traumatic brain injury: 
systematic review and meta-analysis. PloS One 9:e106680 CrossRef Medline

Csuka E, Morganti-Kossmann MC, Lenzlinger PM, Joller H, Trentz O, Kossmann T (1999) IL-10 levels in cerebrospinal fluid and serum of patients with severe traumatic brain injury: relationship to IL-6, TNF-alpha, TGF-beta1 and blood-brain barrier function. J Neuroimmunol 101:211-221. Medline

De Matteis MA, Morrow JS (2000) Spectrin tethers and mesh in the biosynthetic pathway. J Cell Sci 113 (Pt 13):2331-2343.

Delouche A, Attyé A, Heck O, Grand S, Kastler A, Lamalle L, Renard F, Krainik A (2016) Diffusion MRI: pitfalls, literature review and future directions of research in mild traumatic brain injury. Eur $\mathrm{J}$ Radiol 85:25-30. CrossRef Medline

Di Battista AP, Buonora JE, Rhind SG, Hutchison MG, Baker AJ, Rizoli SB, Diaz-Arrastia R, Mueller GP (2015) Blood biomarkers in moderate-to-severe traumatic brain injury: potential utility of a multi-marker approach in characterizing outcome. Front Neurol 6:110CrossRef Medline

Diaz-Arrastia R, Wang KKW, Papa L, Sorani MD, Yue JK, Puccio AM, McMahon PJ, Inoue T, Yuh EL, Lingsma HF, Maas AIR, Valadka AB, Okonkwo DO, Manley GT, TRACK-TBI Investigators (2014) Acute biomarkers of traumatic brain injury: relationship between plasma levels of ubiquitin C-terminal hydrolase-L1 and glial fibrillary acidic protein. J Neurotrauma 31:19-25. CrossRef

Donato R, Sorci G, Riuzzi F, Arcuri C, Bianchi R, Brozzi F, Tubaro C, Giambanco I (2009) S100B's double life: intracellular regulator and extracellular signal. Biochim Biophys Acta 1793:1008-1022. CrossRef Medline

Doran JF, Jackson P, Kynoch PA, Thompson RJ (1983) Isolation of PGP 9.5, a new human neurone-specific protein detected by high-resolution two-dimensional electrophoresis. J Neurochem 40:1542-1547. Medline

Eng LF, Vanderhaeghen JJ, Bignami A, Gerstl B (1971) An acidic protein isolated from fibrous astrocytes. Brain Res 28:351-354. Medline

Ercole A, Thelin EP, Holst A, Bellander BM, Nelson DW (2016) Kinetic modelling of serum $\mathrm{S100 \textrm {b }}$ after traumatic brain injury. BMC Neurol 16:93 CrossRef Medline

Erickson JA, Grenache DG (2011) Comparison of three assays for quantifying $\mathrm{S}-100 \mathrm{~B}$ in serum. Clin Chim Acta Int J Clin Chem 412:2122-2127. CrossRef Medline

Fassbender K, Rossol S, Kammer T, Daffertshofer M, Wirth S, Dollman M, Hennerici M (1994) Proinflammatory cytokines in serum of patients with acute cerebral ischemia: kinetics of secretion and relation to the extent of brain damage and outcome of disease. $J$ Neurol Sci 122:135-139. CrossRef

Faul M, Coronado V (2015) Epidemiology of traumatic brain injury. Handb Clin Neurol 127:3-13. CrossRef Medline

Faul M, Xu L, Wald M, Coronado V (2010) Traumatic brain injury in the United States: emergency department visits, hospitalizations, and deaths 2002-2006. Atlanta, GA: Centers for Disease Control and Prevention.

Fimlab Laboratories Oy (n.d.) Laboratory Manual. Available at: http:// www.fimlab.fi/sivu.tmpl?sivu_id=32 (Accessed September 22, 2016).

Franz G, Beer R, Kampfl A, Engelhardt K, Schmutzhard E, Ulmer H, Deisenhammer F (2003) Amyloid beta 1-42 and tau in cerebrospinal fluid after severe traumatic brain injury. Neurology 60:14571461. Medline

Frugier T, Morganti-Kossmann MC, O’Reilly D, McLean CA (2010) In situ detection of inflammatory mediators in post mortem human brain tissue after traumatic injury. J Neurotrauma 27:497-507. CrossRef Medline

Gabbita SP, Scheff SW, Menard RM, Roberts K, Fugaccia I, Zemlan FP (2005) Cleaved-tau: a biomarker of neuronal damage after traumatic brain injury. J Neurotrauma 22:83-94. CrossRef Medline

Garner CC, Tucker RP, Matus A (1988) Selective localization of messenger RNA for cytoskeletal protein MAP2 in dendrites. Nature 336:674-677. CrossRef Medline
Gatson JW, Barillas J, Hynan LS, Diaz-Arrastia R, Wolf SE, Minei JP (2014) Detection of neurofilament-H in serum as a diagnostic tool to predict injury severity in patients who have suffered mild traumatic brain injury. J Neurosurg 121:1232-1238. CrossRef Medline

Gebhardt C, Lichtenberger R, Utikal J (2016) Biomarker value and pitfalls of serum S100B in the follow-up of high-risk melanoma patients. J Dtsch Dermatol 14:158-164. CrossRef Medline

Goedert M, Spillantini MG, Jakes R, Rutherford D, Crowther RA (1989) Multiple isoforms of human microtubule-associated protein tau: sequences and localization in neurofibrillary tangles of Alzheimer's disease. Neuron 3:519-526. Medline

Graham MR, Pates J, Davies B, Cooper SM, Bhattacharya K, Evans PJ, Baker JS (2015) Should an increase in cerebral neurochemicals following head kicks in full contact karate influence return to play?. Int J Immunopathol Pharmacol 28:539-546. CrossRef Medline

Hallén M, Carlhed R, Karlsson M, Hallgren T, Bergenheim M (2008) A comparison of two different assays for determining S-100B in serum and urine. Clin Chem Lab Med 46:1025-1029. CrossRef Medline

Hayakata T, Shiozaki T, Tasaki O, Ikegawa H, Inoue Y, Toshiyuki F, Hosotubo H, Kieko F, Yamashita T, Tanaka H, Shimazu T, Sugimoto H (2004) Changes in CSF S100B and cytokine concentrations in early-phase severe traumatic brain injury. Shock (Augusta Ga) 22:102-107. CrossRef

Hellewell S, Semple BD, Morganti-Kossmann MC (2016) Therapies negating neuroinflammation after brain trauma. Brain Res 1640: 36-56. CrossRef Medline

Herrmann M, Jost S, Kutz S, Ebert AD, Kratz T, Wunderlich MT, Synowitz H (2000) Temporal profile of release of neurobiochemical markers of brain damage after traumatic brain injury is associated with intracranial pathology as demonstrated in cranial computerized tomography. J Neurotrauma 17:113-122. CrossRef Medline

Ho L, Zhao W, Dams-O'Connor K, Tang CY, Gordon W, Peskind ER, Yemul S, Haroutunian V, Pasinetti GM (2012) Elevated plasma MCP-1 concentration following traumatic brain injury as a potential "predisposition" factor associated with an increased risk for subsequent development of Alzheimer's disease. J Alzheimers Dis 31:301-313. CrossRef Medline

Hofman PA, Stapert SZ, van Kroonenburgh MJ, Jolles J, de Kruijk J, Wilmink JT (2001) MR imaging, single-photon emission CT, and neurocognitive performance after mild traumatic brain injury. Am $\mathrm{J}$ Neuroradiol 22:441-449. Medline

Honda M, Tsuruta R, Kaneko T, Kasaoka S, Yagi T, Todani M, Fujita M, Izumi T, Maekawa T (2010) Serum glial fibrillary acidic protein is a highly specific biomarker for traumatic brain injury in humans compared with S-100B and neuron-specific enolase. J Trauma 69:104-109. CrossRef

Hospital District of Helsinki and Uusimaa (n.d.) Laboratory Manual. Available at: www.huslab.fi/ohjekirja (Accessed September 22, 2016).

Hospital District of Southwest Finland (n.d.) Laboratory Manual. Available at: http://webohjekirja.mylabservices.fi/TYKS/ (Accessed September 22, 2016).

Hughes DG, Jackson A, Mason DL, Berry E, Hollis S, Yates DW (2004) Abnormalities on magnetic resonance imaging seen acutely following mild traumatic brain injury: correlation with neuropsychological tests and delayed recovery. Neuroradiology 46:550-558. CrossRef Medline

Iliff JJ, Chen MJ, Plog BA, Zeppenfeld DM, Soltero M, Yang L, Singh I, Deane R, Nedergaard M (2014) Impairment of glymphatic pathway function promotes tau pathology after traumatic brain injury. $J$ Neurosci 34:16180-16193. CrossRef

lliff JJ, Wang M, Liao Y, Plogg BA, Peng W, Gundersen GA, Benveniste $H$, Vates GE, Deane R, Goldman SA, Nagelhus EA, Nedergaard M (2012) A paravascular pathway facilitates CSF flow through the brain parenchyma and the clearance of interstitial solutes, including amyloid $\beta$. Sci Transl Med 4:147ra111CrossRef Medline 
Ilvesmäki T, Luoto TM, Hakulinen U, Brander A, Ryymin P, Eskola H, Iverson GL, Ohman J (2014) Acute mild traumatic brain injury is not associated with white matter change on diffusion tensor imaging. Brain J Neurol 137:1876-1882. CrossRef Medline

Inglese M, Makani S, Johnson G, Cohen BA, Silver JA, Gonen O, Grossman RI (2005) Diffuse axonal injury in mild traumatic brain injury: a diffusion tensor imaging study. J Neurosurg 103:298-303. CrossRef Medline

Jeter CB, Hergenroeder GW, Hylin MJ, Redell JB, Moore AN, Dash PK (2013) Biomarkers for the diagnosis and prognosis of mild traumatic brain injury/concussion. J Neurotrauma 30:657-670. CrossRef Medline

Johnson VE, Stewart W, Weber MT, Cullen DK, Siman R, Smith DH (2016) SNTF immunostaining reveals previously undetected axonal pathology in traumatic brain injury. Acta Neuropathol (Berl) 131:115-135. CrossRef

Kasantikul V, Shuangshoti S (1989) Positivity to glial fibrillary acidic protein in bone, cartilage, and chordoma. J Surg Oncol 41:22-26. Medline

Kobeissy F, Moshourab RA (2015) Autoantibodies in CNS trauma and neuropsychiatric disorders: a new generation of biomarkers. In: Brain neurotrauma: molecular, neuropsychological, and rehabilitation aspects (Kobeissy FH, editor) Frontiers in Neuroengineering. Boca Raton, FL: CRC Press/Taylor \& Francis. Available at: http://www.ncbi.nlm.nih.gov/books/NBK299208/ (Accessed August 19, 2016).

Kossmann T, Stahel PF, Lenzlinger PM, Redl H, Dubs RW, Trentz O, Schlag G, Morganti-Kossmann MC (1997) Interleukin-8 released into the cerebrospinal fluid after brain injury is associated with blood-brain barrier dysfunction and nerve growth factor production. J Cereb Blood Flow Metab 17:280-289.

Kulbe JR, Geddes JW (2016) Current status of fluid biomarkers in mild traumatic brain injury. Exp Neurol 275 Pt 3:334-352. CrossRef Medline

Kumar RG, Boles JA, Wagner AK (2015) Chronic inflammation after severe traumatic brain injury: characterization and associations with outcome at 6 and 12 months postinjury. J Head Trauma Rehabil 30:369-381. CrossRef Medline

Latov N, Nilaver G, Zimmerman EA, Johnson WG, Silverman AJ, Defendini R, Cote L (1979) Fibrillary astrocytes proliferate in response to brain injury: a study combining immunoperoxidase technique for glial fibrillary acidic protein and radioautography of tritiated thymidine. Dev Biol 72:381-384. Medline

Lee JY, Lee CY, Kim HR, Lee C-H, Kim HW, Kim JH (2015) A role of serum-based neuronal and glial markers as potential predictors for distinguishing severity and related outcomes in traumatic brain injury. J Korean Neurosurg Soc 58:93-100. CrossRef Medline

Lei J, Gao G, Feng J, Jin Y, Wang C, Mao Q, Jiang J (2015) Glial fibrillary acidic protein as a biomarker in severe traumatic brain injury patients: a prospective cohort study. Crit Care (Lond Engl) 19:362 CrossRef

Liliang P-C, Liang C-L, Weng H-C, Lu K, Wang K-W, Chen H-J, Chuang J-H (2010) Tau proteins in serum predict outcome after severe traumatic brain injury. J Surg Res 160:302-307. CrossRef Medline

Ma M, Lindsell CJ, Rosenberry CM, Shaw GJ, Zemlan FP (2008) Serum cleaved tau does not predict postconcussion syndrome after mild traumatic brain injury. Am J Emerg Med 26:763-768. CrossRef

Magnoni S, Esparza TJ, Conte V, Carbonara M, Carrabba G, Holtzman DM, Zipfel GJ, Stocchetti N, Brody DL (2012) Tau elevations in the brain extracellular space correlate with reduced amyloid- $\beta$ levels and predict adverse clinical outcomes after severe traumatic brain injury. Brain J Neurol 135:1268-1280. CrossRef

Maier B, Schwerdtfeger K, Mautes A, Holanda M, Müller M, Steudel WI, Marzi I (2001) Differential release of interleukines 6, 8, and 10 in cerebrospinal fluid and plasma after traumatic brain injury. Shock (Augusta Ga) 15:421-426. Medline

Mannix R, Eisenberg M, Berry M, Meehan WP, Hayes RL (2014) Serum biomarkers predict acute symptom burden in children after concussion: a preliminary study. J Neurotrauma 31:1072-1075. CrossRef Medline

Marchi N, Bazarian JJ, Puvenna V, Janigro M, Ghosh C, Zhong J, Zhu T, Blackman E, Stewart D, Ellis J, Butler R, Janigro D (2013) Consequences of repeated blood-brain barrier disruption in football players. PloS One 8:e56805 CrossRef Medline

McAllister TW, Flashman LA, McDonald BC, Saykin AJ (2006) Mechanisms of working memory dysfunction after mild and moderate TBI: evidence from functional MRI and neurogenetics. J Neurotrauma 23:1450-1467. CrossRef Medline

McDonald BC, Saykin AJ, McAllister TW (2012) Functional MRI of mild traumatic brain injury (mTBI): progress and perspectives from the first decade of studies. Brain Imaging Behav 6:193-207. CrossRef Medline

Mercier E, Boutin A, Lauzier F, Fergusson DA, Simard J-F, Zarychanski R, Moore L, Mclntyre LA, Archambault P, Lamontagne F, Légaré F, Randell E, Nadeau L, Rousseau F, Turgeon AF (2013) Predictive value of $S-100 \beta$ protein for prognosis in patients with moderate and severe traumatic brain injury: systematic review and meta-analysis. BMJ 346:f1757 Medline

Metting Z, Wilczak N, Rodiger LA, Schaaf JM, van der Naalt J (2012) GFAP and S100B in the acute phase of mild traumatic brain injury. Neurology 78:1428-1433. CrossRef Medline

Michetti F, Massaro A, Russo G, Rigon G (1980) The S-100 antigen in cerebrospinal fluid as a possible index of cell injury in the nervous system. J Neurol Sci 44:259-263. Medline

Missler U, Wiesmann M, Wittmann G, Magerkurth O, Hagenström H (1999) Measurement of glial fibrillary acidic protein in human blood: analytical method and preliminary clinical results. Clin Chem 45:138-141. Medline

Mondello S, Buki A, Barzo P, Randall J, Provuncher G, Hanlon D, Wilson D, Kobeissy F, Jeromin A (2014) CSF and plasma amyloid- $\beta$ temporal profiles and relationships with neurological status and mortality after severe traumatic brain injury. Sci Rep 4:6446 CrossRef Medline

Mondello S, Gabrielli A, Catani S, D'Ippolito M, Jeromin A, Ciaramella $A$, Bossù $P$, Schmid K, Tortella $F$, Wang KKW, Hayes RL, Formisano $R$ (2012a) Increased levels of serum MAP-2 at 6-months correlate with improved outcome in survivors of severe traumatic brain injury. Brain Inj 26:1629-1635.

Mondello S, Linnet A, Buki A, Robicsek S, Gabrielli A, Tepas J, Papa L, Brophy GM, Tortella F, Hayes RL, Wang KK (2012b) Clinical utility of serum levels of ubiquitin C-terminal hydrolase as a biomarker for severe traumatic brain injury. Neurosurgery 70:666675.

Moore BW (1965) A soluble protein characteristic of the nervous system. Biochem Biophys Res Commun 19:739-744. Medline

Moore IE, Buontempo JM, Weller RO (1987) Response of fetal and neonatal rat brain to injury. Neuropathol Appl Neurobiol 13:219 228. Medline

Morris M, Maeda S, Vossel K, Mucke L (2011) The many faces of tau. Neuron 70:410-426. CrossRef Medline

Müller K, Elverland A, Romner B, Waterloo K, Langbakk B, Undén J, Ingebrigtsen $T$ (2006) Analysis of protein S-100B in serum: a methodological study. Clin Chem Lab Med 44:1111-1114. CrossRef Medline

Neselius S, Zetterberg H, Blennow K, Randall J, Wilson D, Marcusson J, Brisby H (2013) Olympic boxing is associated with elevated levels of the neuronal protein tau in plasma. Brain Inj 27:425-433. CrossRef Medline

Olivecrona Z, Bobinski L, Koskinen L-OD (2015) Association of ICP, CPP, CT findings and S-100B and NSE in severe traumatic head injury. Prognostic value of the biomarkers. Brain Inj 29:446-454. CrossRef Medline

Oliver J, Abbas K, Lightfoot JT, Baskin K, Collins B, Wier D, Bramhall JP, Huang J, Puschett JB (2015) Comparison of neurocognitive testing and the measurement of marinobufagenin in mild traumatic brain injury: a preliminary report. J Exp Neurosci 9:67-72. CrossRef Medline 
Olivera A, Lejbman N, Jeromin A, French LM, Kim H-S, Cashion A, Mysliwiec V, Diaz-Arrastia R, Gill J (2015) Peripheral total tau in military personnel who sustain traumatic brain injuries during deployment. JAMA Neurol 72:1109-1116. CrossRef Medline

Olsson A, Csajbok L, Ost M, Höglund K, Nylén K, Rosengren L, Nellgård B, Blennow K (2004) Marked increase of beta-amyloid(142) and amyloid precursor protein in ventricular cerebrospinal fluid after severe traumatic brain injury. J Neurol 251:870-876. CrossRef

Ottens AK, Stafflinger JE, Griffin HE, Kunz RD, Cifu DX, Niemeier JP (2014) Post-acute brain injury urinary signature: a new resource for molecular diagnostics. J Neurotrauma 31:782-788. CrossRef Medline

Papa L, Akinyi L, Liu MC, Pineda JA, Tepas JJ, Oli MW, Zheng W, Robinson G, Robicsek SA, Gabrielli A, Heaton SC, Hannay HJ, Demery JA, Brophy GM, Layon J, Robertson CS, Hayes RL, Wang KKW (2010) Ubiquitin C-terminal hydrolase is a novel biomarker in humans for severe traumatic brain injury. Crit Care Med 38:138144. CrossRef

Papa L, Brophy GM, Welch RD, Lewis LM, Braga CF, Tan CN, Ameli NJ, Lopez MA, Haeussler CA, Mendez Giordano DI, Silvestri S, Giordano P, Weber KD, Hill-Pryor C, Hack DC (2016a) Time course and diagnostic accuracy of glial and neuronal blood biomarkers GFAP and UCH-L1 in a large cohort of trauma patients with and without mild traumatic brain injury. JAMA Neurol 73:551-560.

Papa L, Lewis LM, Silvestri S, Falk JL, Giordano P, Brophy GM, Demery JA, Liu MC, Mo J, Akinyi L, Mondello S, Schmid K, Robertson CS, Tortella FC, Hayes RL, Wang KKW (2012) Serum levels of ubiquitin $\mathrm{C}$-terminal hydrolase distinguish mild traumatic brain injury from trauma controls and are elevated in mild and moderate traumatic brain injury patients with intracranial lesions and neurosurgical intervention. J Trauma Acute Care Surg 72: 1335-1344. CrossRef

Papa L, Mittal MK, Ramirez J, Ramia M, Kirby S, Silvestri S, Giordano P, Weber K, Braga CF, Tan CNS, Ameli NJ, Lopez M, Zonfrillo MR (2016b) In children and youth with mild and moderate traumatic brain injury GFAP out-performs $S 100 \beta$ in detecting traumatic intracranial lesions on CT. J Neurotrauma 33:58-64.

Papa L, Robertson CS, Wang KKW, Brophy GM, Hannay HJ, Heaton S, Schmalfuss I, Gabrielli A, Hayes RL, Robicsek SA (2015a) Biomarkers improve clinical outcome predictors of mortality following non-penetrating severe traumatic brain injury. Neurocrit Care 22:52-64.

Papa L, Silvestri S, Brophy GM, Giordano P, Falk JL, Braga CF, Tan CN, Ameli NJ, Demery JA, Dixit NK, Mendes ME, Hayes RL, Wang KKW, Robertson CS (2014) GFAP out-performs $S 100 \beta$ in detecting traumatic intracranial lesions on computed tomography in trauma patients with mild traumatic brain injury and those with extracranial lesions. J Neurotrauma 31:1815-1822. CrossRef

Papa L, Zonfrillo MR, Ramirez J, Silvestri S, Giordano P, Braga CF, Tan CN, Ameli NJ, Lopez M, Mittal MK (2015b) Performance of glial fibrillary acidic protein in detecting traumatic intracranial lesions on computed tomography in children and youth with mild head trauma. Acad Emerg Med off 22:1274-1282.

Paus T, Collins DL, Evans AC, Leonard G, Pike B, Zijdenbos A (2001) Maturation of white matter in the human brain: a review of magnetic resonance studies. Brain Res Bull 54:255-266. Medline

Pearn ML, Niesman IR, Egawa J, Sawada A, Almenar-Queralt A, Shah SB, Duckworth JL, Head BP (2016) Pathophysiology associated with traumatic brain injury: current treatments and potential novel therapeutics. Cell Mol Neurobiol Advance online publication. doi:10.1007/s10571-016-0400-1.

Peeters W, van den Brande R, Polinder S, Brazinova A, Steyerberg EW, Lingsma HF, Maas AIR (2015) Epidemiology of traumatic brain injury in Europe. Acta Neurochir (Wien) 157:1683-1696. CrossRef Medline

Plog BA, Dashnaw ML, Hitomi E, Peng W, Liao Y, Lou N, Deane R, Nedergaard M (2015) Biomarkers of traumatic injury are transported from brain to blood via the glymphatic system. J Neurosci 35:518-526. CrossRef Medline
Puvenna V, Brennan C, Shaw G, Yang C, Marchi N, Bazarian JJ, Merchant-Borna K, Janigro D (2014) Significance of ubiquitin carboxy-terminal hydrolase L1 elevations in athletes after subconcussive head hits. PloS One 9:e96296 CrossRef Medline

Raad M, Nohra E, Chams N, Itani M, Talih F, Mondello S, Kobeissy F (2014) Autoantibodies in traumatic brain injury and central nervous system trauma. Neuroscience 281:C:16-23. CrossRef Medline

Ramont L, Thoannes H, Volondat A, Chastang F, Millet M-C, Maquart F-X (2005) Effects of hemolysis and storage condition on neuron-specific enolase (NSE) in cerebrospinal fluid and serum: implications in clinical practice. Clin Chem Lab Med 43:12151217. CrossRef Medline

Rider CC, Taylor CB (1975) Evidence for a new form of enolase in rat brain. Biochem Biophys Res Commun 66:814-820. Medline

Roberts GW, Gentleman SM, Lynch A, Murray L, Landon M, Graham DI (1994) Beta amyloid protein deposition in the brain after severe head injury: implications for the pathogenesis of Alzheimer's disease. J Neurol Neurosurg Psychiatr 57:419-425. Medline

Rodríguez-Rodríguez A, Egea-Guerrero JJ, León-Justel A, GordilloEscobar E, Revuelto-Rey J, Vilches-Arenas A, Carrillo-Vico A, Domínguez-Roldán JM, Murillo-Cabezas F, Guerrero JM (2012) Role of S100B protein in urine and serum as an early predictor of mortality after severe traumatic brain injury in adults. Clin Chim Acta 414:228-233. CrossRef

Rubenstein R, Chang B, Davies P, Wagner AK, Robertson CS, Wang KKW (2015) A novel, ultrasensitive assay for tau: potential for assessing traumatic brain injury in tissues and biofluids. J Neurotrauma 32:342-352. CrossRef

Santarsieri M, Kumar RG, Kochanek PM, Berga S, Wagner AK (2015) Variable neuroendocrine-immune dysfunction in individuals with unfavorable outcome after severe traumatic brain injury. Brain Behav Immun 45:15-27. CrossRef Medline

Shahim P, Tegner Y, Wilson DH, Randall J, Skillbäck T, Pazooki D, Kallberg B, Blennow K, Zetterberg H (2014) Blood biomarkers for brain injury in concussed professional ice hockey players. JAMA Neurol 71:684-692. CrossRef Medline

Shaw G, Yang C, Ellis R, Anderson K, Parker Mickle J, Scheff S, Pike B, Anderson DK, Howland DR (2005) Hyperphosphorylated neurofilament NF-H is a serum biomarker of axonal injury. Biochem Biophys Res Commun 336:1268-1277. CrossRef

Shibahashi K, Doi T, Tanaka S, Hoda H, Chikuda H, Sawada Y, Takasu Y, Chiba K, Nozaki T, Hamabe Y Ogata T (2016) The serum phosphorylated neurofilament heavy subunit as a predictive marker for outcome in adult patients after traumatic brain injury. $\mathrm{J}$ Neurotrauma 30:1826-1833. CrossRef

Siman R, Giovannone N, Hanten G, Wilde EA, McCauley SR, Hunter JV, Li X, Levin HS, Smith DH (2013) Evidence that the blood biomarker SNTF predicts brain imaging changes and persistent cognitive dysfunction in Mild TBI patients. Front Neurol 4:190. CrossRef Medline

Siman R, Shahim P, Tegner Y, Blennow K, Zetterberg H, Smith DH (2015) Serum SNTF increases in concussed professional ice hockey players and relates to the severity of postconcussion symptoms. J Neurotrauma 32:1294-1300. CrossRef Medline

Siman R, Toraskar N, Dang A, McNeil E, McGarvey M, Plaum J, Maloney E, Grady MS (2009) A panel of neuron-enriched proteins as markers for traumatic brain injury in humans. J Neurotrauma 26:1867-1877. CrossRef Medline

Šimić G, Babić Leko M, Wray S, Harrington C, Delalle I, JovanovMilošević N, Bažadona $\mathrm{D}$, Buée $\mathrm{L}$, de Silva RD, Giovanni $\mathrm{G}$, Wischik C, Hof PR (2016) Tau protein hyperphosphorylation and aggregation in Alzheimer's disease and other tauopathies, and possible neuroprotective strategies. Biomolecules 6:6, doi: 10.3390/biom6010006.

Skogseid IM, Nordby HK, Urdal P, Paus E, Lilleaas F (1992) Increased serum creatine kinase BB and neuron specific enolase following head injury indicates brain damage. Acta Neurochir (Wien) 115:106-111. Medline 
Slobounov SM, Gay M, Zhang K, Johnson B, Pennell D, Sebastianelli W, Horovitz S, Hallett M (2011) Alteration of brain functional network at rest and in response to YMCA physical stress test in concussed athletes: RsFMRI study. Neurolmage 55:1716-1727. CrossRef Medline

Sorci G, Bianchi R, Giambanco I, Rambotti MG, Donato R (1999) Replicating myoblasts and fused myotubes express the calciumregulated proteins S100A1 and S100B. Cell Calcium 25:93-106. CrossRef Medline

Steinman L (1996) Multiple sclerosis: a coordinated immunological attack against myelin in the central nervous system. Cell 85:299302. Medline

Stocchero CMA, Oses JP, Cunha GS, Martins JB, Brum LM, Zimmer ER, Souza DO, Portela LV, Reischak-Oliveira A (2014) Serum S100B level increases after running but not cycling exercise. Appl Physiol Nutr Metab 39:340-344. CrossRef

Strathmann FG, Schulte S, Goerl K, Petron DJ (2014) Blood-based biomarkers for traumatic brain injury: evaluation of research approaches, available methods and potential utility from the clinician and clinical laboratory perspectives. Clin Biochem 47:876-888. CrossRef Medline

Studer M, Goeggel Simonetti B, Heinks T, Steinlin M, Leichtle A, Berger S, Joeris A (2015) Acute S100B in serum is associated with cognitive symptoms and memory performance 4 months after paediatric mild traumatic brain injury. Brain Inj 29:1667-1673. CrossRef Medline

Takala RS, Posti JP, Runtti H, Newcombe VF, Outtrim J, Katila AJ, Frantzén J, Ala-Seppälä H, Kyllönen A, Maanpää H-R, Tallus J, Hossain MI, Coles JP, Hutchinson P, van Gils M, Menon DK, Tenovuo O (2016) GFAP and UCH-L1 as outcome predictors in traumatic brain injury. World Neurosurg 87:8-20. CrossRef Medline

Teasdale G, Jennet B (1974) Assessment of coma and impaired consciousness. A practical scale. Lancet 304:81-84. CrossRef

Teasdale G, Maas A, Lecky F, Manley G, Stocchetti N, Murray G (2014) The Glasgow Coma Scale at 40 years: standing the test of time. Lancet Neurol 13:844-854. CrossRef Medline

Tharp WG, Sarkar IN (2013) Origins of amyloid- $\beta$. BMC Genomics 14:290 CrossRef Medline

Thelin EP, Johannesson L, Nelson D, Bellander B-M (2013) S100B is an important outcome predictor in traumatic brain injury. $\mathrm{J}$ Neurotrauma 30:519-528. CrossRef Medline

Thelin EP, Nelson DW, Bellander B-M (2014) Secondary peaks of $\mathrm{S} 100 \mathrm{~B}$ in serum relate to subsequent radiological pathology in traumatic brain injury. Neurocrit Care 20:217-229. CrossRef Medline

Thomas DG, Palfreyman JW, Ratcliffe JG (1978) Serum-myelinbasic-protein assay in diagnosis and prognosis of patients with head injury. Lancet Lond Engl 1:113-115. Medline

Tolan NV, Vidal-Folch N, Algeciras-Schimnich A, Singh RJ, Grebe SKG (2013) Individualized correction of neuron-specific enolase (NSE) measurement in hemolyzed serum samples. Clin Chim Acta 424:216-221. CrossRef

Townend W, Dibble C, Abid K, Vail A, Sherwood R, Lecky F (2006) Rapid elimination of protein S-100B from serum after minor head trauma. J Neurotrauma 23:149-155. CrossRef Medline

Trojanowski JQ, Walkenstein N, Lee VM (1986) Expression of neurofilament subunits in neurons of the central and peripheral nervous system: an immunohistochemical study with monoclonal antibodies. J Neurosci 6:650-660.

Tsitsopoulos PP, Marklund N (2013) Amyloid- $\beta$ peptides and tau protein as biomarkers in cerebrospinal and interstitial fluid following traumatic brain injury: a review of experimental and clinical studies. Front Neurol 4:79. CrossRef Medline

Tuttolomondo A, Pecoraro R, Pinto A (2014) Studies of selective TNF inhibitors in the treatment of brain injury from stroke and trauma: a review of the evidence to date. Drug Des Devel Ther 8:2221-2238. CrossRef Medline
Undén J, Bellner J, Eneroth M, Alling C, Ingebrigtsen T, Romner B (2005) Raised serum S100B levels after acute bone fractures without cerebral injury. J Trauma 58:59-61. Medline

Undén L, Calcagnile O, Undén J, Reinstrup P, Bazarian J (2015) Validation of the Scandinavian guidelines for initial management ofminimal, mild and moderate traumatic brain injury in adults. BMC Med 13:292. CrossRef Medline

Undén J, Ingebrigtsen T, Romner B and the Scandinavian Neurotrauma Committee (2013) Scandinavian guidelines for initial management of minimal, mild and moderate head injuries in adults: an evidence and consensus-based update. BMC Med 11:50. CrossRef Medline

Undén J, Romner B (2010) Can low serum levels of S100B predict normal CT findings after minor head injury in adults? An evidencebased review and meta-analysis. J Head Trauma Rehabil 25:228240. CrossRef Medline

University of Eastern Finland, Brain Research Unit (n.d.) Alzheimer research. Available at: http://www2.uef.fi/en/alzheimermarkkeritutkimukset (Accessed September 22, 2016).

Vajtr D, Benada O, Linzer P, Sámal F, Springer D, Strejc $P$, Beran $M$, Průša R, Zima T (2012) Immunohistochemistry and serum values of S-100B, glial fibrillary acidic protein, and hyperphosphorylated neurofilaments in brain injuries. J Ev Purkyne 57: $7-12$.

Vivekanandan S, Brender JR, Lee SY, Ramamoorthy A (2011) A partially folded structure of amyloid-beta(1-40) in an aqueous environment. Biochem Biophys Res Commun 411:312-316. CrossRef Medline

Wang KK, Posmantur R, Nath R, McGinnis K, Whitton M, Talanian RV, Glantz SB, Morrow JS (1998) Simultaneous degradation of alphall- and betall-spectrin by caspase 3 (CPP32) in apoptotic cells. J Biol Chem 273:22490-22497. Medline

Wang KK, Yang Z, Yue JK, Zhang Z, Winkler EA, Puccio AM, Diaz-Arrastia R, Lingsma HF, Yuh EL, Mukherjee P, Valadka AB, Gordon WA, Okonkwo DO, Manley GT, Cooper SR, DamsO'Connor K, Hricik AJ, Inoue T, Maas Al, Menon DK, et al. (2016) Plasma anti-glial fibrillary acidic protein autoantibody levels during the acute and chronic phases of traumatic brain injury: a transforming research and clinical knowledge in traumatic brain injury pilot study. J Neurotrauma 33:1270-1277. CrossRef

Weingarten MD, Lockwood AH, Hwo SY, Kirschner MW (1975) A protein factor essential for microtubule assembly. Proc Natl Acad Sci U S A 72:1858-1862. Medline

Welch RD, Ayaz SI, Lewis LM, Unden J, Chen JY, Mika VH, Saville B, Tyndall JA, Nash M, Buki A, Barzo P, Hack D, Tortella FC, Schmid K, Hayes RL, Vossough A, Sweriduk ST, Bazarian JJ (2016) Ability of serum glial fibrillary acidic protein, ubiquitin C-terminal hydrolase-L1, and S100B to differentiate normal and abnormal head computed tomography findings in patients with suspected mild or moderate traumatic brain injury. J Neurotrauma 33:203214. CrossRef Medline

Wilkinson KD, Lee KM, Deshpande S, Duerksen-Hughes P, Boss JM, Pohl J (1989) The neuron-specific protein PGP 9.5 is a ubiquitin carboxyl-terminal hydrolase. Science 246:670-673. CrossRef

Witman GB, Cleveland DW, Weingarten MD, Kirschner MW (1976) Tubulin requires tau for growth onto microtubule initiating sites. Proc Natl Acad Sci U S A 73:4070-4074. Medline

Wolf H, Krall C, Pajenda G, Hajdu S, Widhalm H, Leitgeb J, Sarahrudi $\mathrm{K}$ (2016) Preliminary findings on biomarker levels from extracerebral sources in patients undergoing trauma surgery: potential implications for TBI outcome studies. Brain Inj 30:1220-1225. CrossRef Medline

Yamazaki Y, Yada K, Morii S, Kitahara T, Ohwada T (1995) Diagnostic significance of serum neuron-specific enolase and myelin basic protein assay in patients with acute head injury. Surg Neurol 43:267-271. Medline 
Yokobori S, Hosein K, Burks S, Sharma I, Gajavelli S, Bullock R (2013) Biomarkers for the clinical differential diagnosis in traumaticbrain injury-a systematic review. CNS Neurosci Ther 19:556565. CrossRef

Zemlan FP, Rosenberg WS, Luebbe PA, Campbell TA, Dean GE, Weiner NE, Cohen JA, Rudick RA, Woo D (1999) Quantification of axonal damage in traumatic brain injury: affinity purification and characterization of cerebrospinal fluid tau proteins. J Neurochem 72:741-750. Medline

Zetterberg H, Blennow K (2015) Fluid markers of traumatic brain injury. Mol Cell Neurosci 66:99-102. CrossRef Medline
Zetterberg H, Smith DH, Blennow K (2013) Biomarkers of mild traumatic brain injury in cerebrospinal fluid and blood. Nat Rev Neurol 9:201-210. CrossRef Medline

Zhang Z, et al. (2014) Human traumatic brain injury induces autoantibody response against glial fibrillary acidic protein and its breakdown products. PloS One 9:e92698. CrossRef Medline

Žurek J, Fedora M (2012) The usefulness of S100B, NSE, GFAP, $\mathrm{NF}-\mathrm{H}$, secretagogin and Hsp70 as a predictive biomarker of outcome in children with traumatic brain injury. Acta Neurochir (Wien) 154:93-103. 